Embodied negotiations: identity, space and livelihood after trade zones in the Dominican Republic

\author{
Marion Werner \\ Department of Geography, \\ University at Buffalo, SUNY \\ Buffalo, \\ USA \\ marion.werner@gmail.com
}




\title{
Embodied negotiations: identity, space and livelihood after trade zones in the Dominican Republic
}

\begin{abstract}
In this article, I analyze socio-spatial processes of subject-making at the center of the restructuring of export industries. To do so, I develop the concept of 'embodied negotiations' to explain the spatial and corporeal experience of trade zone workers reproduced as migrants with the collapse of garment exports in the Dominican Republic. Drawing on ethnographic research, I examine 'rural return' as both a livelihood strategy and a discourse shaped by inter-related gender and racial ideologies of labour as well as the uneven transnationalization of rural and urban localities. I show how the negotiation of social position by subjects marked by race, gender and class is always also a negotiation of spatial position in and between localities structured through raced, gendered and class relations. Men's efforts to remain in urban areas as a form of social 'whitening' are compared to women's resistance to rural return as an attempt to stay in circulation as paid labour. Overall, I argue that feminist research on global production should be 'spatialized' by attending to livelihoods and practices of subject-making that emerge in parallel to export restructuring.
\end{abstract}

Keywords: gender, race, embodiment, global production, Dominican Republic 


\section{Introduction: rethinking the spaces and subjects of global production}

Like many countries in the Caribbean, the Dominican Republic undertook an intensified program of manufactured export promotion in the 1980s. This new accumulation strategy was premised on employing a majority of young, female workers. Feminist studies of this process in and beyond the Caribbean have continued to analyze the gendered effects of the 'global assembly line' at the level of the factory and the household. These are far from stable production arrangements, however; complex processes of worker incorporation and expulsion continually remake uneven geographies of globalization. My objective in this article is to understand how subjectivity and its relationship to place are reconfigured when employment in export manufacturing sectors collapses. To do this, I analyze material and social processes of subject-making at the center of labour-intensive export restructuring. I explore how gender and race shape the possibility of rural return for former garment workers reproduced as migrants following the decline of garment exports in the Dominican Republic.

I focus on former garment workers retrenched from the main free trade zone (FTZ) of Santiago de los Caballeros (henceforth, Santiago), the second largest city in the country and the center of export garment production. Built in 1973, the FTZ in Santiago was the third export zone to be established in the country. Trade zone production was minimal until the early 1980s when US trade policy under President Reagan authorized tariff-free access for assembled goods produced from US inputs. ${ }^{1}$ The Dominican Republic's relative political stability, and the enthusiasm for the FTZ model by provincial industrialists excluded from import-substitution incentives, combined with structural 
adjustment regimes to create a formidable boom in employment and assembled exports (Isa Contreras, et al. 2003; Moya Pons 1992; Schrank 2003). Between 1980 and 1990, the number of trade zones increased from three, employing 16,000 workers, to 25 , employing 130,000 workers (CNZFE 1999). By 1990, the World Bank estimated that the Dominican Republic alone represented one-fifth of all employment in trade zones worldwide, three-quarters of which was dedicated to producing apparel for the US market (1992).

Trade zones and their homologues, maquilas, are key spatial regimes studied by feminist scholars in order to understand the connections between gender, embodiment, subjectivity and global production. ${ }^{2}$ Studies have focused on gendered migration decisions to trade zones (Fernández-Kelly 1983; Safa 1995), gendered practices of labour control within them (Ong 1987; Salzinger 2003), the impact of women's labour in trade zones on household composition and decision-making (Chant and McIlwaine 1995; Cravey 1998; Wolf 1992), and, circular migration between rural villages and export factories (Silvey 2000). Early critical literature challenged essentialist constructions of gender deployed by transnational firms and foreign exchange-strapped states to promote export-led accumulation dependent upon labour devalued through gendered norms such as dexterity and docility (Benería and Roldán 1987; Elson and Pearson 1981; FernándezKelly 1983; Mies 1982; Nash and Fernandez-Kelly 1983). Post-structuralist studies have since looked at how gendered labour regimes materialize through everyday practices in export factories, constructing feminized labour (or not) in the process (Ngai 2005; Salzinger 2003; Wright 2006). Attention to subject production in this literature contemplates the variation of gender regimes that exist across export factories as well as 
complex identity formations of race, ethnicity, rural provenance, sexuality and caste, as well as gender (cf. Fernandes 1997; Yelvington 1995). Post-structuralist approaches also underwrite a rethinking of the boundary between subject production and consumption in relation to global circuits of discourse and commodity production (Brooks 2007; Joseph 1998).

Material-discursive approaches to global production are variously situated in relation to Judith Butler's work on performative subjectivity, or the theoretical underpinnings of her work in Foucauldian analysis of power. Butler argues that the normative subject (e.g., the heterosexual subject) is defined through marking the boundary between an apparently purified subject field and that which must be repudiated, disavowed, or rendered abject (i.e., expulsed) (1993). This process of boundary-making is never complete; rather, Butler's deconstruction of subjectivity develops the notion of sex as a performative effect of the iterative practices to define the field of discourse and power as a purified Subject. Feminist geographers have criticized Butler's approach to subjectivity for evacuating space from this corporeal process, projecting space as a schematic field rather theorizing it as a simultaneously corporeal and social process (Rose 1999). ${ }^{3}$ Furthermore, reading Butler and Foucault in their specific locations, postcolonial theorists have argued that their theorizations of power are centered on seemingly self-contained western models (Cheah 1996 cited in Pratt 2004; Spivak 1988; Stoler 1995). These weaknesses, however, need not constitute a premise to reject performative approaches but rather to consider how subject production intersects with specific modalities of power that work unevenly across space (Ong 2000; Pratt 2004). While identity performance and strategies of bodily control in the workplace - and in 
particular, the factory floor - can be read to 'spatialize' Butler's theory in this way, in this article, I spatialize subjectivity in relation to global production through an analysis of subject production in spaces of livelihood upon factory closure.

The relationship between embodied subjectivities, migration and work is receiving renewed attention in feminist and critical development geography (Gidwani and Sivaramakrishnan 2003; McDowell 2008; Silvey and Lawson 1999). These studies provide important insights to de-center the analysis of embodied production of subjects from the capitalist wage-labour process to multiple spaces of cultural and social production that exist outside formal workplaces like factories (Chari and Gidwani 2005). Eschewing deterministic approaches, the migration literature draws on social theory and ethnographic methods '[to] explore the ways in which migrants negotiate and inhabit multiple subject positions, which in turn shape their mobility decisions and experiences' (Silvey and Lawson 1999, 127). In the Hispanic Caribbean context, this literature is suggestive of an understanding of the negotiation of social position by embodied subjects marked by race, gender and class as always also a negotiation of spatial position in localities where labour is simultaneously raced and gendered (cf. Gregory 2007).

Here, I spatialize the study of global production by considering how the materialization of embodied subjects is intertwined with retrenched workers' efforts to locate themselves as embodied subjects after factory closure (Grosz 1995). I contrast dominant discourses that render garment workers as abject subjects in Santiago to the embodied positioning of former workers who risk abjection as gendered, sexualized, racialized and non-waged bodies. I discuss migrant workers' practices and narratives of positioning their working bodies to create spatial and social distance from non- or lesser 
subject positions. These practices are part of an on-going process of subject-making in relation to ideologies of gender, race and labour that intersect with differently transnationalized rural and urban places. I term these practices of location 'embodied negotiations,' and explore them through discourses surrounding the Santiago trade zone's crisis and the practices of former factory workers to position their bodies socially and spatially after the trade zone's employment collapse.

The approach I take to interpreting the narratives and practices of former garment workers is simultaneously a condition of the production of knowledge about these men's and women's livelihood strategies. In order to research these strategies, I conducted multi-sited fieldwork based for four months at the employers' association in the Santiago trade zone followed by six months focused on research with laid-off garment workers, the latter following Ferguson's longitudinal method of study of displaced miners (1999), and adjusting my method and approach in the context of a weakly organized, ${ }^{4}$ mixed-gender factory workforce. I focused my study on workers retrenched from a single firm in the Santiago FTZ called IA that produced jeans and casual pants for major brands and retailers in the US. The firm was employing 5,900 workers when it announced that it would close. My relationship to workers was facilitated by two union federations, each with an affiliate union at IA. In the weeks prior to IA's closure, I was invited to observe union meetings as workers made decisions about demands for severance and shared information related to the firm. Consequently, my key informants were union activists who facilitated relationships with their former co-workers, both former union members and non-union workers. My interviews and repeat visits with former garment workers from IA took place in two urban neighbourhoods next to the trade zone and in three small 
towns, or campos, ${ }^{5}$ where migrants had returned. Our research encounters occurred across hierarchical differences of race, gender and class, and, as former garment workers often reminded me, our opposite conditions of labour wherein my paid work was inextricably linked to their unemployment. My account of these negotiations, then, is a partial glimpse at a process of subject production, a process that can neither be separated from, nor reduced to, the research relationship (Haraway 1991; Nagar and Geiger 2007).

The article is organized in six sections. Section two details the patterns of labour and capital flows in the sub-national region known as the Cibao where the export garment sector was centered and where the sending communities I studied were located. Section three explains the recent trajectory of the export garment industry, focusing on its consolidation in the Cibao, the masculinization of its workforce, and the contraction of its employment. The forth section briefly discusses discourses of criminality and rural return surrounding the trade zone's employment collapse in Santiago. Sections five and six focus on 'rural return' from the perspective of migrant workers let go from IA. Men's and women's narratives and practices suggest that the cultural politics of labour in rural spaces structured their decisions about rural return along uneven gendered lines. While men negotiated a racial politics of labour that devalued their work in rural areas, women expressed the impossibility of return as the impossibility of finding paid labour in rural hometowns. The reading of these narratives in relation to dominant discourses illustrates the complex social and spatial terrain of subject production after the collapse of trade zone employment. The article concludes by arguing for spatializing the subjects of global production by attending to multiple spaces and embodied practices of livelihood. 


\section{Regional places: production and migration in the Cibao}

The inland city of Santiago has long served as a commercial center for the surrounding region, called the Cibao. The region experienced high levels of outmigration in the period following the end of the country's 31-year dictatorship in 1961. Trade zones were responsible for a partial reversal in out-migration from the region, orienting a proportion of migrant movements to these proximate sources of employment temporarily or permanently. In this section, I elaborate how labour mobilities were produced in relation to intra- and interregional and international flows of labour and capital in the Cibao, linked to transformations in domestic and export agriculture, in addition to export manufacturing.

In comparison to plantation agriculture in the east and its system of large landholdings (latifundio), the Cibao is notable for a relatively diversified system of land tenure based largely on small- and medium-sized plots (minifundios and fincas medias) (San Miguel 1997). In addition to subsistence crops such as yucca, beans and corn, historically, small and medium peasant producers cultivated tobacco, and later cacao and coffee, for export. In the twentieth century, while continuing to cultivate these secondary commercial crops, the state promoted domestic agricultural production (especially rice) to supply food to the booming export sugar economy in the east (Ibid; Yunen 1985). This spatial division of labour between a landed, relatively independent peasantry and a monocrop plantation system coincided with a regional cum racialized division of agrarian labour. The country's main export, sugar, employed primarily Haitian migrant and resident labourers. Haitians worked and settled mostly in the country's eastern sugar 
region and were confined to that region through legal restrictions, discrimination and territorial controls.

In the 1970s, the Dominican Republic suffered the effects of an intense crisis in sugar exports and state-promoted import-substitution industries supported by sugar returns (Betances 1995). The crisis would profoundly transform the position of rural inhabitants in the Cibao in two ways. First, the socio-spatial segmentation of agricultural labour changed. On the heels of the export sugar crisis, Haitian labour was incorporated more widely into other commercial crops such as coffee and rice production, widely integrating into Cibaeño agriculture for the first time (Lozano 2001: 283-295). The incorporation of Haitian labourers into Cibaeño agriculture was concomitant with growing numbers of underemployed Dominican men in the Cibao (Dore y Cabral 1981; Lozano 2001).

Second, and deeply related, the region experienced intense out-migration, both internally, mostly to the capital city, and internationally. By the 1980s, Dominicans had become the third largest migrant stream to the US (Castro and Boswell 2002). Emigration had profound effects on social relations in the Cibao, the results of which were studied in several sending communities during that decade. Remittance incomes and production strategies of land-holding households with members who had emigrated were found to increase class polarization in Cibaeño campos and to hasten the pace of rural proletarianization (Grasmuck and Pessar 1991; Ravelo and del Rosario 1986). The gender ideology restricting women's activities to the home and patio, following the white/mestizo elite patriarchal ideal, was reinforced in remittance receiving households. In these households, the restriction of women to unpaid household and informal home- 
based labour increased the social standing of families. Simultaneously, growing numbers of women from land- and/or capital-poor households, those less likely to migrate internationally, increasingly sought paid work as domestic workers (often in the households of emigrant women) and, as we will see, in trade zones (Georges 1990; Safa 1995; cf. Freeman 2002).

Beginning in the 1980 s, facing a balance of payments crisis, the country underwent two rounds of structural adjustment, devaluing its currency and diversifying exports from sugar to export assembly (Isa Contreras et al. 2003; Espinal 1995). Trade zones proliferated in secondary cities and towns in the second half of the decade largely concentrated in the Cibao. In fact, the manufactured export sector mildly attenuated outmigration from the region (Ariza 2000; Santana 1994). Trade zones contributed to the decentralization of urban growth from the capital city and an increase in migrants, especially young, married $^{6}$ and single women, moving to towns and cities to work in these new factories. The participation of women as wage workers in trade zones intensified material connections between rural campos and provincial capitals and secondary towns where these zones were located. In addition to remittances, Dominican women commonly migrated to trade zones without their children, leaving them in the care of maternal or paternal grandmothers in their hometowns or campos (Safa 1995). Women's migration to and wage labour in trade zones constituted a contradictory terrain of exploitation and opportunity. The change in export strategy was accompanied by transformations in household relations, in the composition of households (i.e., an increased number of women-headed households amongst trade zone migrants), and in 
structural links between low-wage formal employment and the feminization of labour informality (Ariza 2000; Ariza 2004; Itzigsohn 2000; Safa 1990; Safa 1995).

\section{Regional consolidation, masculinization and unemployment in the Dominican garment industry}

The initial boom and spectacular growth of the Dominican garment sector was curtailed in the mid-1990s by the entrance of producers from the circum-Caribbean and Mexico competing for US market share, particularly once Mexico became party to a trade agreement with the US and Canada (the North American Free Trade Agreement, or NAFTA). Nevertheless, the outcome of the new regional trade agreement defied dire predictions. Santiago-based firms, many of them Dominican-owned, were considerably more resilient than their competitors in the capital and the eastern region of the country. As a result, production consolidated in Santiago and surrounding towns in the central Cibao and employment expanded (Schrank 2003).

Following NAFTA, these same firms, together with other trade zone entrepreneurs in the circum-Caribbean, successfully lobbied the US government for a form of NAFTA-parity that would permit duty-free exports for garments that underwent pre- and post-assembly operations in the macro-region. As has been noted elsewhere, the incorporation of non-assembly functions in garment production is coincident with a degree of masculinization of the workforce (Fernández-Kelly 1983; Nanda 2000). While women constituted nearly $65 \%$ of the garment workforce for much of the 1990 s, this proportion declined in the latter years of the decade. By 2004, women made up 54\% of 
the garment workforce nation-wide. In the Santiago-based firms, however, men in the garment sector constituted 55\% of the workforce (CZFIS 2005). In addition to changes in the labour process, this shift was due to a re-gendering of sewing and skill, as well as, as I indicate below, the devaluing of rural men's labour in the Cibao.

Despite the sector's resilience in the 1990s, in recent years, garment production has suffered a precipitous contraction due in large part to the implementation of new multilateral trade rules. In 2005, the final phase-out of long-standing quotas on trade in textile products was implemented under the World Trade Organization-brokered Agreement on Textiles and Clothing. Since the elimination of quotas, garment exports from the circum-Caribbean have been in more direct competition with like products from Asia. $^{7}$ The effects in the Dominican Republic have been particularly doleful. In the three years following the quota phase-out, employment in the garment industry fell by $56 \%$, from 131,978 to 58,546 (CNZFE 2007). Due to the consolidation of the industry in the Cibao, the region experienced the bulk of employment loss. The Santiago trade zone reported some 14 firm closures and 29,000 jobs lost between 2004 and 2007 as owners were either unable or unwilling to produce under new structural conditions.

\section{Risky positions: discourses of trade zone unemployment and rural return in Santiago}

The collapse of trade zone employment gave rise to several discourses surrounding the livelihood activities of fired workers. While informal sector activity had previously been documented in the press and policy reports as an additional benefit of the export model, as factory closures continued, an increase 
in informal activities was asserted and framed as a danger both to remaining trade zone producers and to tranquility in the city. During the layoffs, for example, the trade zone's management reinforced the zone's perimeter, adding additional rows of cement block to the walls, replacing barbed wire with circular razor wire, and sealing two of its five entrances. Management justified new security measures claiming that the economic activity on the perimeter of the zone was increasingly illicit, including prostitution, drug-dealing and contraband. $^{8}$

The perception that the increase in informal activity marked a proliferation of abject subjects (i.e., drug dealers and sex workers) was linked not only to the spaces and neighbourhoods around the trade zone but to the problem of workers seen to be out of place in the city. The mayor of Santiago, for example, declared the following:

The economic and moral problem of Santiago is that so many trade zone companies have had to close. This has brought a big problem to Santiago because [it is] a city of 750,000 inhabitants, but with $65 \%$ of them coming from other towns, people who live in Santiago and worked in the trade zone but who haven't left regrettably... There are stands and stands on every corner... And there are also some who we know are already in jail because they have turned to criminal activity (delincuencia). ${ }^{9}$

The mayor framed the employment crisis as exclusively a migrant crisis, desiring the city to be a conditional residence for migrants. Unregulated work was constructed as the providence of migrants irrespective of workers' places of birth or the number of years they had lived in Santiago. Thus, in dominant discourse, informal economic activity (especially street vendors) did not index a problem of urban unemployment but rather a 
problem of intransigent migrants whose failure to respond 'rationally' to their subject position (i.e., to migrate) constructed them as potential criminals.

The impacts of both unemployment and out-migration were profoundly experienced by residents in working class neighbourhoods who described a significant exodus of migrant workers to hometowns or to tourist poles in the east. They pointed to the many pensiones (buildings with one-room apartments rented by the week by trade zone workers) for sale and the high numbers of residential vacancies. Santana ${ }^{10}$, a $22-$ year resident of the Cienfuegos neighbourhood next to the trade zone and a staff member of a local job retraining center, described the multiple livelihood strategies he was observing:

There are some, I know a few zoneros [trade zone workers] who have stands to sell chinas [cut fruit] on the corner. Today I saw two this morning, one was a supervisor. But those are just the ones I know. There are few jobs. A big proportion has left to their place of origin, to Dajabón, to San Juan... [Before,] in order to leave the neighbourhood, you had to wake up very early because it was a terrible mess and you would see lines and lines of people. The carros [collective taxis] were full and you couldn't get one. Now, no, you can leave at any hour in the morning and the carros are empty. That's the unemployment. ${ }^{11}$

While discourses criminalizing unemployed workers point to the risky practices that women and men faced in positioning their labouring bodies after trade zones in the city, 'rural return' was also a prospect that was conditioned by abject subject positions. Below, I explore how former garment workers, all migrants, negotiated the possibilities for livelihood between spaces and subject positions in the city and in their hometowns. I found that men's and women's discourses of livelihood after trade zones communicated a resistance to rural return framed around distancing their bodies from abject subjectivities that they associated with return to their campos. Male migrants depicted the risk of being 
reinscribed as de-valued, racialized rural labour, while women migrants resisted rural returns that constructed them as unpaid household labour in dependent household relations. Discourses of rural return and observations of livelihood practices of return migrants in their hometowns suggest how the performance of modern subjectivity was constantly being negotiated in relation to these differently gendered and racialized places.

\section{Race, masculinity and rural return on the threshold of unemployment}

In this section, I unpack men's discourses about the possibility of rural return together with observations from follow-up visits with return male migrants in their campos. Men's narratives about rural return revealed how hierarchies of desirable labour were conditioned by cultural meanings of work as well as by wages (Gidwani and Sivaramakrishnan 2003). Here, I focus primarily on the racialization of rural labour as a key discourse through which men constructed their resistance to rural return and foreclosed the possibility for their labour in rural areas. I place these narratives in the context of Dominican gendered and racial ideologies of labour. This discussion suggests how migratory decisions of former male garment workers following factory closure constitute an embodied negotiation of their position in raced and gendered localities.

Ramón, Andri and Hector are each originally from different campos in the central Cibao, while Monica is from a campo in the eastern Cibao. Monica introduced me to her male co-workers. All four were of mixed-race descent. ${ }^{12}$ We first spoke two weeks after the factory had closed on the small patio in front of Monica's two-room apartment near the Santiago trade zone, which she shared with her husband, also a former IA worker, and their son. Ramón, 26, is the father of three. He worked at IA for ten years and his last 
position in the plant was as a utiliti, filling any operation needed on the production line.

Ramón explained his desire to stay in the city:

I have few friends left [in the campo] and it's expensive to travel with my kids. Anyway, I have all the relaxation I need with them here. I don't need to go to the campo for that. The mentality there is different. [MW: In what way?] In the city, everything is cleaner. You use good clothes and they are clean. In the morning, you shower and put on clean clothes but in the campo you get up and put on muddy clothes from the day before and go to work... My grandmother still lives there with five of my uncles. My family had some land and used to grow cacao, coffee, plantains, oranges... Now, maybe they have a hectare or two but nothing is being cultivated. You can also study in the city while in the campo you can only finish eighth grade. I finished seventh grade before I left and took eighth grade here. I got to the third year of high school. But it was difficult because companies won't respect your study schedule. I'm not going back to the campo. I don't like the idea. ${ }^{13}$

Here, Monica decided to expand on Ramón's point: 'Era prieto y ahora es rubio.' [He was dark and now he is blonde.] Monica used the word 'prieto,' a disparaging term for black phenotype often associated with Dominican anti-Haitianism. Ramón agreed: 'Claro, tengo otro color.' [Of course, I have a different colour.]

The other two men nodded in agreement. Andri, 26, continued. He had been brought to the city by his older sister after finishing grade eight. His campo was near La Vega where his mother still lived, whom he visited every couple of months. Although he came to Santiago to continue school, he stopped studying once his sister got him the job at IA. He worked for the next eight years, becoming a utíliti, like Ramón, at IA. He and the other two men agreed emphatically that there was no going back to chapeando [clearing ground] with a machete. Hector, 36, was from Alta Mira, close to Santiago, and had worked in trade zones for 14 years and in IA for the past 11 . His last job at the plant was in finishing, attaching cardboard labels to the beltline of pants. He had a small plot 
in his campo not far from Santiago and traveled there frequently. He had worked with horses and livestock there, never with a machete, he emphasized, in reference to Andri's comment about manual rural labour as a kind of going backwards. The livestock had long been sold and he said that he could not return to working with a machete since he had never done so.

Ramón, Andri and Hector's narrative about their devalued labour in el campo and their ascent to connecting this narrative with Monica's description of social whitening suggests that race, class and masculinity formed a lived experience of social and spatial position that was open to re-signification by the movement of their working bodies in space, a movement spawned by structural changes in capitalist accumulation but not solely determined by them. Ramón's depiction of the campo as a place for relaxation rather than labour created further distance between his livelihood strategy in Santiago and the possibility of return to his home village. The exchange between these former garment workers provides a partial perspective into how class is lived as an embodied social and spatial position cross-cut with gendered and racial ideologies of labour (cf. Hall 1980).

In the Dominican context, the contemporary distance between social blackness and phenotypic traits has been analyzed in relation to the colonial order and the peculiarity of defining Dominican nationhood in contrast to Haiti (Fischer 2004; TorresSaillant 1998a; 1998b). The panic amongst Creole elites occasioned by the Haitian revolution opened up this distance, as social blackness came to signify not only slaves but those who resisted colonial power. The modern state, consolidated since the 1930s by the Dominican dictator Trujillo, inherited this negrophobic predilection and reworked it for the purposes of nation building through an ideology of Dominicanidad, predicated on 
Hispanidad [white, Spanish-ness], negrophobia and anti-Haitianism (Howard 2001; Turits 2003; Candelario 2007). Historian Silvio Torres-Saillant has proposed an understanding of contemporary Dominican working class identity in relation to the colonial and postcolonial period. He argues that the distance between social blackness and phenotypic blackness permits Dominicans of colour to 'step outside the sphere of their blackness, [enabling] them to remain whole' in the face of state negrophobia (1998a, 136).

Following Torres-Saillant, I want to suggest that the narrative of migrant male trade zone workers, combined with practices in el campo that I discuss below, were part of a daily performance of modern subjectivity in part conditioned by the struggle of Dominican working class men to resist being inscribed as socially black. Social whitening was achieved through a combination of living in urban spaces, taking on an urban look, and engaging in forms of labour socially constructed as 'modern,' which these workers associated with factory work. Yet, the response of Ramón suggests that the re-signification of race through these embodied practices was itself never stable: having another colour (tengo otro color) is a way of expressing a temporary state - like being cold or being sleepy. With the factory's closure, Ramón and his co-workers stood on the unstable threshold that held open the possibility of their labouring bodies being resignified as socially black.

Conversation with return male migrants in their hometowns revealed a range of activities as well as narratives about their return. Of the ten men I interviewed who had returned to their campos in the five months following the factory's closure, only one was engaged full-time in farming. Some men were taking on odd jobs and subsisting on the 
largely reciprocal and gift economies of their home communities until they might migrate again. This was popularly referred to as picando, or nibbling, a way to sustain oneself without getting ahead. In rural areas, this was a decidedly masculinized livelihood form, reflecting the more restricted mobility of women in rural spaces that I discuss below.

Some former male trade zone workers had accumulated enough money, largely through severance pay, to allow them to integrate into informal commercial circuits in their campos, activities facilitated by rural social networks and in-flows of remittances in those communities with a high proportion of international migrants. For example, some men acquired motorcycles and worked as motoconchos, or motorcycle taxis, in their hometowns. Motoconchos were well suited to transport the small quantities of inputs and products associated with small scale farming along narrow, dirt roads.

While unregulated work in the city had been drawn upon to re-signify unemployed workers as migrants and criminals, return migrants engaging in unregulated or illicit trading could circumvent criminalization because of their social position in their campos. For example, Miguel, 44, returned to his wife's campo where he had forged close ties during his 12 years in the Santiago trade zone, the last six in finishing at IA. He was working for a wood processing workshop in the back of his in-law's house. Miguel's income came from trading in trees and finding buyers. 'It is called contraband,' he explained. 'If the police catch you here, you have to pay them a few hundred pesos,' he continued, 'but if they catch you up in the mountain, they make you plant 100 trees and charge a big fine.' Like Miguel, in many cases, commercial activities existed at the margins of state regulation. The stigmatizing of Miguel's labour as informal or illegal by 
the state was lessened by his sociospatial position as a local in his campo, leading to less harsh penalties by the police.

The narratives and activities described in this section illustrate how former male trade zone workers' embodied negotiations of livelihood were linked to malleable constructions of social blackness, constructions that were associated with kinds of work and particular gendered and racial politics of labour in rural and urban places. These narratives and observations suggest that part of these workers' struggle was to find livelihood options that positioned their working bodies on the modern end of a potentially punitive and inextricably gendered and racialized spectrum of labour. While Ramón, Andri and Hector sought to avoid the abject social position of rural labourer by staying in the city, return male migrants navigated their positions within the campo in multiple ways. The negotiation of social position was not guaranteed by staying in Santiago or returning to home villages; rather, gendered and racial constructions of labour intersecting in each locality constituted the spectrum that these workers negotiated.

\section{6. 'There's no work for women there': women and rural return in La Torre, Cibao}

The embodied negotiations of former garment workers are inseparable from the gendering of productive and reproductive labour. This process of gendering and its variation across villages, towns and cities emerged as the primary narrative through which former female garment workers described their livelihood possibilities. In this section, I focus on two women from a campo called La Torre in the eastern Cibao and their considerations of return in relation to their possibilities for sexual and economic 
independence. While former male garment workers' negotiated the cultural politics and economic prospects for their paid labour in their campos, women's narratives suggest that gendered constructions of paid work in their campos and related household hierarchies meant that their return would reproduce them as unpaid household labour. ${ }^{14}$

Yesenia, 26, worked for eight years in the Santiago trade zone, and spent the last five in IA as a final auditor (i.e. line inspection). Her mother cared for her four-year-old son in La Torre. Yesenia's narrative about her livelihood choices revealed a negotiation between her efforts to exert control over how her body was sexualized and gendered and how she negotiated the limits to her control through migration. She shared varied reasons for not wanting to return to her campo, a narrative that was constantly evolving as she adapted to and struggled to rework her livelihood options, and eventually, to return for what she hoped would be a temporary stay. Yesenia first explained her reasons for resisting rural return in terms of losing an urban look: 'There, I eat too much and with my body type, I gain weight.' Like her male counterparts, clothing and an urban look were part of Yesenia's concerns. However, these concerns also extended to her body's shape. ${ }^{15}$ Yesenia continued with her preoccupations about what she would do in her campo:

I am not very open to the idea of living in el campo. I left when I was 11, first to San Francisco [Macorís, the provincial capital] and then to Santo Domingo and then Santiago. But all the same, there's money in el campo, a lot of rice, farming, coffee, cacao. In Nagua [the nearest town], there's a restaurant and a car wash now. I prefer to go for brief stays, maybe 15 or 20 days. But to sit around and not work... There's no work for women there. I had a stand once where I sold chicken, salad and root vegetables. I had good clients and whenever I am back they ask if I plan to start up the business again. If I go back, I will, but I got sick working with the chickens. ${ }^{16}$

Yesenia's possibilities for rural return were unique amongst the women I interviewed, linked to the location of her mother's house in the center of La Torre, and 
what she described as a relatively dynamic economic context. La Torre was located at the crossroads of the Dominican Republic's changing accumulation model. The relative economic dynamism that Yesenia depicted was linked not only to extensive rice production in the region, but also to the predominance of remittance incomes in the community, as well as a new highway being built through the area to facilitate tourist travel. The temporary highway project, sustained remittances, and rice production expanded commercial and service activities. As I have described, however, these jobs were gendered as male. Increased commercial activity did not significantly change gender ideologies of women's movement in small towns and villages. Yesenia negotiated these norms through a home-based business, earning an income from the increasingly commodified relations in her campo.

Although Yesenia earned more money from her business than in the trade zone because she did not incur many expenses ${ }^{17}$ her reluctance to return was associated both with more strict control of her income and movements by her mother, and the presence of her son's father in her campo. Yesenia shared considerations about her livelihood options linked with her desires to be in a relationship with a man who had money and would be her primary partner. She explained that her son's father was a receiver of significant remittances. He used the economic power associated with these funds to maintain a sexual relationship with Yesenia, despite being remarried with three children. Yesenia felt ashamed by the relationship with her son's father, especially when living in La Torre, close to his wife. She was sure that if she moved back to her campo, the father of her son would 'make [her] life difficult.' 
Other former female garment workers resisting rural return shared similar dilemmas about negotiating their sexual and wage independence in hometowns where paid labour for women was largely unavailable. Laya, 26, and Domingo, 38, a couple from La Torre, had both been working at IA since 2000. Laya moved to another garment export factory where she continued to work as a taqueadora (cross-stitching belt loops). With the closure of IA, Domingo lost his job in finishing (pressing pants) and reluctantly returned to cultivating rice on his father's 60 tareas (3.75 ha). Laya remained in Santiago with their two children earning a wage largely to cover her costs of rent and childcare in the city. She was hoping to keep her job in order to accrue sufficient severance pay to buy her own house in el campo and set up her own business. She was clear and adamant about her strategy, despite Domingo's desire for her immediate return to his parent's house. Laya planned to work for as long as possible in Santiago in order to create a place for her paid labour in her campo, as well as independence from her husband and his family.

Migrant women's negotiation of their position with respect to unpaid domestic work was certainly not guaranteed by staying in Santiago: most of the women migrants I interviewed who were staying in the city were looking for paid work with little success. They were either engaged primarily in unpaid household labour (and dependent on spousal support in cases where they had partners) or working as domestic workers. Nevertheless, these women argued that to return to their campos was to foreclose the possibility of their paid labour. ${ }^{18}$ To stay in Santiago then was to position themselves as labouring bodies that could occupy the subject position of paid worker. The exclusion of women's paid labour in rural villages and towns was not a property of rural areas, as 
static or traditional; rather, as the comparison to men's rural return suggests, the gendering of labour in rural areas was an effect of the way that intimate, regional and transnational connections were woven through rural localities.

\section{Embodied negotiations: spatializing the subjects of global production}

By examining men's and women's experiences after trade zones, the challenges and possibilities of analyzing complex subject positions and their relationship to capital accumulation become clearer (see McDowell 2008). For former male garment workers, keeping social and spatial distance from agrarian labour, constructed as an abject position through race, class and gender hierarchies, is one manifestation of embodied positioning. This strategy leads to multiple practices depending on migrant men's connections to and possibilities for livelihood within their campos. Within the structuring of race, class and gender experienced by Dominican women, the gendering of labour appears as a dominant relation although inseparable from complex race/class hierarchies. The white/mestizo patriarchal ideal of the male-headed household, one that was always unevenly materialized in the Dominican context, has undergone contradictory changes through the transnationalization of campos and the incorporation/expulsion of women into and from paid work. Nevertheless, former female garment workers' narratives suggest that this ideal household structure continues to gender paid labour in campos as male. Staying in the city thus remains a key strategy to stay in circulation as potential paid labour. Finally, the social and spatial positioning of garment workers' to reproduce themselves as 
subjects demonstrates the interconnections between accessing 'modern' forms of labour and embodied performances of consumption.

The 'global assembly line' does not describe a static spatial order but a process of renewing capitalist accumulation through the on-going definition, management and reworking of socio-spatial difference. In the context of mobile capital and multiple systems of livelihood (semi-agrarian, transnational migrant, urban informal and waged), subjects are produced in part through the capitalist labour process but perhaps more so through its very instability. Capital's performative myth of the disposable Third World woman worker so effectively detailed in the work of Melissa Wright (2006) has its counterpart in workers' on-going practices of embodied negotiations. Thus the subjects of flexibilized and transnational labour processes are produced not only in factories but through the practices of the migrant body and the places of livelihood that constitute the subject's material and social reproduction. These strategies are forged in and between localities that are unevenly structured through racialized, gendered and class relations. At the threshold of the idled garment factory, these multiple practices of subject-making come to the fore and reveal the diverse subjects of labour that animate the uneven reconfigurations of global production.

\section{Acknowledgements}

This article is based on research funded by the Interdiscplinary Center for the Study of Global Change and writing support from the Graduate School, both at the University of Minnesota. I am greatly indebted to the former workers of IA who shared their experiences, opinions and lives with me, as well as the trade zone association and the 
unions for their co-operation. I am grateful for careful reading and input from Richa Nagar, Jennifer Bair, Sara Koopman, Diana Ojeda, Jen Gieseking, Sandy Brown, Jaume Franquesa, Altha Cravey, Michaeline Crichlow and three anonymous reviewers. All errors and weaknesses of interpretation are mine.

\section{Notes on Contributor}

Marion Werner received her Ph.D. in Geography from the University of Minnesota in 2010 and held a Social Sciences and Humanities Research Council of Canada Post-Doctoral Fellowship in 2010 at York University. Her research draws upon feminist political economy and postcolonial theory to investigate global production networks, trade integration and alternative regionalisms, and constructions of labour in the circum-Caribbean. Other work has appeared in NACLA: Report on the Americas, Environment and Planning A, Acme, and Antipode (forthcoming). She will be starting her appointment as an Assistant Professor at the University at Buffalo (SUNY) in 2011.

\footnotetext{
Notes

${ }^{1}$ In 1983, the US Congress passed the Caribbean Basin Initiative, a package of military aid and trade incentives aimed at securing US hegemony in the face of democratic and revolutionary movements for structural change in the circum-Caribbean. Although initially excluded from tariff exemption, President Reagan expanded the trade provisions of CBI in 1987 to include garments sewn from US textiles, facilitating a garment export boom across the region (see Green 1998; Heron 2004).

${ }^{2}$ I use the term 'global production' to refer to the uneven and dynamic organization of firms, services, and regulation, inseparable from the cultural politics of labour and finance, and historic patterns of uneven development. My characterization draws on Ramamurthy (2004) and contributions in geography by Mullings (2004), Massey (1984) and Henderson, et al. (2002).

${ }^{3}$ The problem is not unique to Butler but could be considered a major shortcoming of structuralism and post-structural deconstruction, especially the tendency to destabilize the
} 
integrity of the Subject (also, Power and Time) through space as a kind of de-centering or disruption rather than thinking through multiple trajectories and their generative spatiotemporal categories (Massey 2005).

${ }^{4}$ Union formation requires 20 workers to sign a legal request; there is no limit to the number of unions in a workplace. Collective bargaining requires $50 \%$ plus one of the workforce to be affiliated to a single union. In 2003, before the downturn, nine out of 531 trade zone firms had collective agreements. No collective agreement has ever been signed in a trade zone in the Cibao region, however. The presence of multiple unions in a single firm greatly reduces the possibility for achieving the majority needed for collective bargaining.

${ }^{5}$ Campo is a polysemic and versatile term with more than 18 meanings in the Real Academia Española. In its use in the Dominican Republic, campo refers to rural areas or the countryside (el campo), a person's natal home in a rural area ( $\mathrm{mi} / \mathrm{su}$ campo), and a cultivated field. The last two meanings indicate the inseparability of family dwellings and agricultural production. Yesenia, for example, described the meaning of el campo as 'El campo, la casa materna, la casa donde uno nació. El campo de origen, donde tu familia, tu papá y tu mamá.' ['El campo, one's maternal house, the house where one was born, el campo of origin, where your family (is), your father and your mother.'] Other interviewees also used the term to distinguish themselves from other migrants that they claimed were from places that were 'more campo' than their own places of origin, referring to the perception of places as isolated or lacking certain markers of 'progress,' like a gas station. I use the Spanish term throughout the article given its rich meaning. ${ }^{6}$ By 'married,' I include consensual unions.

${ }^{7}$ The elimination of quotas on textile products was a change in world trade rules long advocated by countries of the global South as part of their efforts to liberalize import markets of the global North. The outcomes have been uneven and especially detrimental for many producers in the circum-Caribbean (see Werner and Bair 2009).

${ }^{8}$ Author's fieldnotes, Association of Trade Zones of the Northern Region, January 22, 2007.

${ }^{9}$ Quoted in Fernández (2007). All translations are the author's.

${ }^{10}$ I use pseudonyms for names of people and campos in the text.

${ }^{11}$ Author interview, Centro de la Juventud y de la Cultura, Cienfuego, Santiago. October 17, 2006. Early studies of the employment effects of the garment sector downturn noted that rural return was an important strategy in their qualitative summary. Survey research, however, was based solely on individual informants residing in urban neighbourhoods and did not include a method to gauge return migration; therefore, its extent could not be documented quantitatively (Gómez 2007; Tejada Holguin 2007).

${ }^{12}$ For an analysis of the cultural politics of Dominican racial descriptors, see Howard (2001) and Candelario (2007)..

${ }^{13}$ Author's notes, February, 17, 2007.

${ }^{14}$ Women and men described their household relationships to me in heteronormative terms.

${ }^{15}$ A former male IA worker in La Torre reinterpreted this narrative of urban look as a disadvantage rather than as something to be desired, saying 'work [in Santiago] is just for you to keep yourself looking good in the city, not for actually making money.' 
${ }^{16}$ Author's notes. February 18, 2007.

${ }^{17}$ Yesenia estimated her daily earnings through food vending at 200-300 pesos after expenses, or 1200-1800 per week. Yesenia's last base wage in the factory was 1200 pesos per week. She frequently earned between 1500 and 2000 pesos per week with production bonuses. In the last two years of work, Yesenia claimed she was unable to save money because of increasing costs in Santiago (author's notes, April, 2007).

${ }^{18}$ Women's reluctance to return to hometowns and cities has been noted in the context of international migration by Grasmuck and Pessar (1991). Women's experiences negotiating gender norms (of labour, sexuality and household hierarchies) upon return are discussed by Gregory $(2007,69-80)$. 


\section{References}

Ariza, Marina. 2000. Ya no soy la que dejé atrás: Mujeres migrantes en República Dominicana. México: Editorial Plaza y Valdés.

—. 2004. Obreras, sirvientas y prostitutas. Globalización, familia y mercados de trabajo en la República Dominicana. Estudios Sociológicos XXII: 123-149.

Benería, Lourdes and Martha Roldán. 1987. The crossroads of class and gender: industrial homework, subcontracting and household dynamics in Mexico City. Chicago: University of Chicago Press.

Betances, Emilio. 1995. State and Society in the Dominican Republic. Boulder: Westview Press.

Brooks, Ethel C. 2007. Unraveling the Garment Industry: Transnational organizing and women's work. Minneapolis: University of Minnesota Press.

Butler, Judith. 1993. Bodies that Matter: On the discursive limits of "sex." New York: Routledge.

Candelario, Ginetta E.B. 2007. Black Behind the Ears: Dominican Racial Identity from Museums to Beauty Shops. Durham and London: Duke University Press.

Castro, Max J. and Thomas D. Boswell. 2002. The Dominican Diaspora Revisited: Dominicans and Dominican-Americans in a New Century. North-South Agenda Papers 53: 1-25.

Chant, Sylvia and Cathy McIlwaine. 1995. Women of a Lesser Cost: female labour, foreign exchange, and Philippine development. London and Manila: Pluto Press and Ataneo de Manila Press.

Chari, Sharad and Vinay Gidwani. 2005. Introduction: Grounds for a spatial ethnography of labor. Ethnography 6:267-281.

Cheah, Pheng. 1996. Mattering. Diacritics 26:108-139.

Consejo Nacional de Zonas Francas de Exportación (CNZFE). 1999. Informe Estadístico. Santo Domingo, República Dominicana.

—. 2007. Informe Estadístico. Santo Domingo, República Dominicana. Santo Domingo, República Dominicana.

Corporación Zona Franca Industrial de Santiago (CZFIS). 2005. Memorias. Santiago, República Dominicana. 
Cravey, Altha. 1998. Women and Work in Mexico's Maquiladoras. Lanham, MD: Rowman and Littlefield.

Dore y Cabral, Carlos. 1981. Reforma agraria y luchas sociales en la República Dominicana, 1966-1978. República Dominicana: Editora Taller.

Elson, Diane and Ruth Pearson. 1981. 'Nimble Fingers Make Cheap Workers': An analysis of women's employment in Third World export manufacturing. Feminist Review 7: 87-107.

Espinal, Rosario. 1995. Economic Restructuring, Social Protest and Democratization in the Dominican Republic. Latin American Perspectives 22:63-79.

Ferguson, James. 1999. Expectations of Modernity. Berkeley: University of California Press.

Fernandes, Leela. 1997. Producing Workers: The Politics of Gender, Class and Culture in the Calcutta Jute Mills. Philadelphia: University of Pennsylvania Press.

Fernández, H. 2007. Sued: Cierre de zonas francas ha hecho proliferar negocios informales. El Caribe, August 14.

Fernández-Kelly, María-Patricia. 1983. For we are sold, I and my people: Women and Industry in Mexico's Frontier. Albany, NY: SUNY Press.

Fischer, Sibylle. 2004. Modernity Disavowed: Haiti and the Cultures of Slavery in the Age of Revolution. Durham and London: Duke University Press.

Freeman, Carla. 2000. High Tech and High Heels in the Global Economy. Durham, NC: Duke University Press.

Georges, Eugenia. 1990. The Making of a Transnational Community: Migration, Development and Cultural Change in the Dominican Republic. New York: Columbia University Press.

Gidwani, Vinay. and Kalyanakrishnan Sivaramakrishnan. 2003. Circular Migration and the Spaces of Cultural Assertion. Annals of the Association of American Geographers 93:186-213.

Gómez, Carmen J. 2007. República Dominicana. In Un Golpe Más: Los efectos del fin del Acuerdo Multifibras en Centroamérica y República Dominicana, ed. Carmen J Gómez, 385-450. Managua, Nicaragua: PASE/IRSTD.

Grasmuck, Sherri and Patricia. Pessar. 1991. Between Two Islands: Dominican International Migration. Berkeley: University of California Press.

Green, Cecelia. 1998. The Asian Connection: The US-Caribbean Apparel Circuit and a New Model of Industrial Relations. Latin American Research Review 33:7-47. 
Gregory, Steven. 2007. The Devil Behind the Mirror: Globalization and Politics in the Dominican Republic. Berkeley: University of California Press.

Grosz, Elizabeth. 1995. Space, time and perversion: Essays on the politics of bodies. New York and London: Routledge.

Hall, Stuart. 1980. Race, articulation and societies structured in dominance. In Sociological theories: Race and Colonialism, 305-345. Poole, England: UNESCO.

Haraway, Donna. 1991. Simians, Cyborgs, and Women: The Reinvention of Nature. New York: Routledge.

Henderson, Jeffrey, Peter Dicken, Martin Hess, Neil Coe, and Henry W.C. Yeung. 2002. Global production networks and the analysis of economic development. Review of International Political Economy 9: 436-464.

Heron, Tony. 2004. The New Political Economy of United States-Caribbean Relations: The Apparel Industry and the Politics of NAFTA Parity. Hampshire, UK: Ashgate.

Howard, David. 2001. Coloring the Nation: Race and Ethnicity in the Dominican Republic. Oxford: Signal Books.

Isa-Contreras, Pavel, Miguel Ceara-Hatton, and Federico Cuello-Camilo. 2003. Desarrollo y políticas comerciales en la República Dominicana. Santo Domingo: Friedrich Ebert Stiftung and CIECA.

Itzigsohn, José. 2000. Developing Poverty: The State, Labor Market Deregulation, and the Informal Economy in Costa Rica and the Dominican Republic. University Park, Pennsylvania: Pennsylvania State University.

Joseph, Miranda. 1998. The Performance of Production and Consumption. Social Text 54:25-61.

Lozano, Wilfredo. 2001. Los trabajadores del capitalismo exportador. Mercado de trabajo, economía exportadora y sustitución de importaciones en la República Dominicana: 1950-1980. Santo Domingo, República Dominicana: Banco Central de la República Dominicana.

Massey, Doreen. 1984. Spatial Divisions of Labour: Social structures and the geography of production. New York: Routledge.

—. 2005. For Space. London: Sage.

McDowell, Linda. 2008. Thinking through work: complex inequalities, constructions of difference and trans-national migrants. Progress in Human Geography 32: 491507. 
Mies, Maria. 1982. The Lace Makers of Narsapur. Geneva: ILO.

Moya Pons, Frank. 1992. Empresarios en conflicto. Santo Domingo: Fondo Para el Avance de la Ciencias Sociales.

Mullings, Beverley. 2004. Globalization and the territorialization of the new Caribbean service economy. Journal of Economic Geography 4: 275-298.

Nagar, Richa and Susan Geiger. 2007. Reflexivity, Positionality, and Identity in Feminist Fieldwork: Beyond the impasse? In Politics and Practice in Economic Geography, ed. Barnes, Trevor and Eric Sheppard, Adam Tickell, and Jamie Peck, 267-278. London: Sage.

Nanda, Meera. 2000. Post-Fordist Technology and the Changing Patterns of Women's Employment in the Third World. Gender, Technology, and Development 4: 25-59.

Nash, June and Patricia Fernandez-Kelly. 1983. Women, Men and the International Division of Labor. Albany: State University of New York Press.

Ngai, Pun. 2005. Made in China: Women Factory Workers in a Global Workplace. Durham. NC: Duke University Press.

Ong, Aihwa. 1987. Spirits of Resistance and Capitalist Discipline. Albany, NY: State University of New York Press.

—. 2000. Graduated Sovereignty in South-East Asia. Theory, Culture \& Society 17: 5575.

Pratt, Geraldine. 2004. Working Feminism. Philadelphia: Temple University Press.

Ramamurthy, Priti. 2004. Why Is Buying a 'Madras' Cotton Shirt a Political Act? A Feminist Commodity Chain Analysis. Feminist Studies 30:734-769.

Ravelo, Sebastián and Pedro J. del Rosario. 1986. Impacto de los dominicanos ausentes en el financiamiento rural. República Dominicana: Universidad Católica Madre y Maestra.

Rose, Gillian. 1999. Performing Space. In Human Geography Today, ed. Massey, Doreen, John Allen, and Phil Sarre, 247-259. Cambridge: Polity Press.

Safa, Helen. 1990. Women and Industrialisation in the Caribbean. In Women, employment, and the family in the international division of labor, ed. Sharon Stichter and Jane L. Parpart. Philadelphia: Temple University Press.

—. 1995. Myth of the Male Breadwinner. Boulder, CO: Westview Press.

Salzinger, Leslie. 2003. Genders in Production: Making Workers in Mexico's Global Factories. Berkeley: University of California Press. 
San Miguel, Pedro L. 1997. Los campesinos del Cibao: economía de mercado y transformación agraria en la República Dominicana 1880-1960. Puerto Rico: Universidad de Puerto Rico.

Santana, Julio. 1994. Estrategia neoliberal, urbanización, y zonas francas: El caso de Santiago, República Dominicana. Santo Domingo: FLACSO.

Schrank, Andrew. 2003. Luring, Learning, and Lobbying: The Limits to Capital Mobility in the Dominican Republic. Studies in Comparative International Development 37: 89-116.

Silvey, Rachel. 2000. Stigmatized Spaces: gender and mobility under crisis in South Sulawesi, Indonesia. Gender, Place and Culture 7: 143-162.

Silvey, Rachel. and Victoria A. Lawson. 1999. Placing the Migrant. Annals of the Association of American Geographers 89:121-132.

Spivak, Gayatri C. 1988. Can the Subaltern Speak? In Marxism and the Interpretation of Culture, ed. Cary Nelson and Lawrence Grossberg, 271-316. Urbana and Chicago: University of Illinois Press.

Stoler, Ann Laura. 1995. Race and the Education of Desire: Foucault's History of Sexuality and the Colonial Order of Things. Durham, NC: Duke University Press.

Tejada Holguin, Ramón. 2007. Dinámicas del desempleo en el sector textil de las zonas francas de la República Dominicana, entre el 2003 y el 2005. USAID: Women and Development Office, Washington, D.C.

Torres-Saillant, Silvio. 1998a. The Tribulations of Blackness: Stages in Dominican Racial Identity. Latin American Perspectives 25: 126-146.

—. 1998b. Creoleness or Blackness: A Dominican Dilemma. Plantation Society in the Americas V: 29-40.

Turits, Richard L. 2003. Foundations of Despotism: Peasants, The Trujillo Regime, and Modernity in Dominican History. Stanford, CA: Stanford University Press.

Werner, Marion and Jennifer Bair. 2009. After sweatshops? Apparel politics in the circum-Caribbean. NACLA: Report on the Americas. Forthcoming.

Wolf, Diane L. 1992. Factory Daughters: Gender, Household Dynamics, and Rural Industrialization in Java. Berkeley: University of California Press.

World Bank. 1992. Export Processing Zones. Washington, DC.

Wright, Melissa W. 2006. Disposable Women and Other Myths of Global Capitalism. New York and London: Routledge. 
Yelvington, Kevin A. 1995. Producing Power: Ethnicity, Gender, and Class in a Caribbean Workplace. Philadelphia: Temple University Press.

Yunen, Rafael E.. 1985. La isla como es: hipótesis para su comprobación: Universidad Católica Madre y Maestra. 